on he formulated his views uninfluenced by others. $\mathrm{He}$ developed the idea of the libido existing not as a physical craving as Freud envisaged it but as Dr. Jacobi defines it as "the totality of that force which pulses through and combines one with another all the forms and activities of this psychic system" (p. 50). In practice it appears to erupt in conceptions of gods and demons.

Jung made an attempt to return to clinical medicine in his publication of "Psychological Types", in which he described the extravert and introvert. This phase did not persist, and his later books have tended more and more towards obscurity and mysticism. Dr. Jacobi tries to refute this accusation of mysticism by comparing Jung's psychology with the conclusions of Whitehead and Eddington (although these also have been accused of the same fault) but does not do so very effectively. She says: "Before the word 'mystic' one no longer needs to feel the customary dreadabove all, not to confuse it with cheap irrationalism, for it is precisely reason that here presses forward to its own limits, as modern logic likewise honestly attempts to define its own boundaries, not, as it were, by rejecting but by logically establishing the independence, indeed when one has rightly defined and thereby delimited the concept of 'cognition', the sovereignty of the "mystical'" (p. 64). In spite of this attempt to cut the ground away from the critic, it is difficult to describe otherwise than as mystical and obscure the following passage from Dr. Jacobi's book: "The making conscious of those contents which constitute the archetype of the mana personality signifies therefore 'for the man the second and true liberation from the father, for the woman that from the mother, and therefore the first perception of their own unique individuality'. Only when he in the true sense of the word 'becomes united with God in spiritual childhood' ; and then only if he no longer 'blows up' his thus broadened consciousness in order 'thereby paradoxically to lapse into a flooding of his consciousness by the unconscious', i.e. an inflation. Such presumption would indeed, in view of the deep insights he had won, be not astounding; everyone falls victim to it for a time in the course of the individual process" (p. 117).

Well might the reader ask what all this means. Does it imply that the patient might become conceited? One hesitates to say, but Dr. Jacobi states that such nonsense "is likely to have a decisive influence on the formation of the future conception of the world".

If we turn from the consideration of Jung's philosophy to Dr. Jacobi's exposition of it we must admit that her book is thorough and careful. She has made an honest attempt to expound Jung's difficult conceptions, and those who read it will gather some outline of the copious outpourings of the master. The book is divided into three parts : (1) The Nature and Structure of the Psyche; (2) The Laws of the Psychic Processes and Operations; (3) The Practical Application of Jung's Theory. There are a large number of diagrams, but whether they clarify the subject or not it is difficult to say. The book ends with a biographical sketch of Jung's life which seems rather inadequate. There is a complete bibliography (perhaps the most valuable part of the book) which extends to fourteen pages and includes a list of all works in the various languages into which his writings have been translated. There is an index of four and a half pages which seems adequate for a book of this size.
Clifford Allen.

\section{A SOCIAL REVOLUTION}

\section{Science and Human Prospects}

By Prof. Eliot Blackwelder. (The Thinker's Forum, No. 19.) Pp. 32. (London: Watts and Co., Ltd., 1942.) 6d. net.

$7 \mathrm{HE}$ revolution which is in full swing might be dated for Great Britain from mechanical inventions of the latter part of the eighteenth century. She has dealt with scientific and mechanical changes rather than social or governmental, because British history has on the whole been peaceful; but she was able by her resources of coal and iron and the mechanical inventions to beat her neighbours in trade as well as at sea.

It is not necessarily beneficial to undertake a revolution and therefore it would be well in the present movement to specify the good and what might be the better. Prof. Blackwelder's little book suggests some points.

(1) Mechanical force has now been carried almost to the extreme. The steam engine has come into its own. The result of this is the multiplication of the workpeople and the turning of a countryside into a town.

The first fruits of applying science to industry are not all good-great wealth for the proprietors but an ill life for the workpeople. The early part of the last century began the revolution to remedy this. A minimum of welfare was insisted on in factory legislation, and minimum rates of pay were afterwards secured, partly by union action, partly by the State.

(2) The second part of the revolution is ultimately superior. The State by the end of the century had taken education under its care. The English plan in education as well as government is to keep the best of the old and widen as far as resources yield. Although the level is low, knowledge, taste and goodwill to others have increased enormously.

(3) It has often been said that Christianity was never really active until the nineteenth century. And in these later appeals, it is noticeable that freedom is good for health. A benevolent and not dictatorial State is the ideal of the latter part of this revolution. As humanity has come together by the appliances of science, so it must work for higher things in art and music. The outbreak of industrial imperialism which stamped the latter part of the nineteenth century did not aim mainly at the higher things. They are the passionate quarry of the present crusade. A good life for all : any goodness being aimed at, it is seen that religion pervades the whole. Strange that a hundred years ago it was not regarded as irreligious to make fortunes for the few and neglect and degrade the multitude. Is it degrading to work?

The revolution through which we are now passing, aims at something far higher than before. The whole community shares and the State is the ultimate authority; and there will be as many intermediate bodies as needed, for education, for transport, for music and many more agencies, leading always to free initiative.

Beyond this, and more important than this, comes the international body. In this Great Britain will be preponderant, but other States including Germany will have their place. The United States will be at our side and we shall avoid the errors of 1918 in making treaties and excluding the enemy. We cannot believe in a final step back. Humanity which grew out of Western civilization will triumph. It may be long.
F. S. Marvin. 